\title{
Corruption Eradication in the Government's Goods and/or Service Procurement
}

\author{
Jawade Hafidz \\ Magister Kenotariatan \\ Universitas Islam Sultan Agung \\ Semarang, Indonesia \\ jawade.hafidz@yahoo.com
}

\begin{abstract}
In Indonesia, the policies issued by the government to prevent corruption in the procurement of goods and/or government services were not able to work properly in accordance with expectations. This paper aims to examine strategies to eradicate corruption in order to restore the state's losses caused by it. The type of study is a normative legal study traced by statute and conceptual approaches. Data were obtained from the literature study and the book of laws governing the criminal act of corruption. The results show that the eradication of corruption can be done through mental and spiritual coaching from state officials; centralization of government procurement agencies and the simplification of stages in the procurement of government goods and/or services; preventive efforts through ethical, moral, and religious education; as well as social work penalties besides than imprisonment and other fines.
\end{abstract}

Keywords—corruption; state loss; government's goods/services

\section{INTRODUCTION}

The procurement of government goods/services is a fertile land of corruption for bureaucrats or officials because it is here that they can manipulate the budget in various ways to enrich themselves. As a party serving the public interest, the government should implement a credible procurement of goods and/or services. For example, the case of e-identity card corruption is a case of mega corruption in Indonesia, which involves many officials both executive and legislative at this time [1]. There are many cases in government procurement projects, which involve partners and officials as procurement committees that are detrimental to state finances [2].

Lubis and Scott expressed their view of corruption that in the sense of law, corruption is a behavior that benefits selfinterest by harming others, by government officials who directly violate the legal limits of such behavior, whereas according to government norms can be considered corrupt if the law is violated or not in business the action is deplorable [3].

Corruption can be said to be a form of deviant behavior or disgraceful behavior. This deviant behavior as a form of greed in the self-perpetrators who want something that is not his right, the state-owned money that should be used for the benefit of the people, not the opposite. An investigation into corruption has required an experimental design that nevertheless lends itself to credible findings [4]
Corruption is a serious concern for business organizations all over the world [5]. Corruption by public officials causes harm to the state's economy. All plans and execution of government decisions in the field of economy and finance will be hindered, resulting in manipulation efforts due to the opening of opportunities to corrupt. Despite the widespread awareness of the negative effects that corruption has on growth and development and the proliferation of international and national anti-corruption laws, corruption remains rampant [6]. Corrupt governments or officials can only be 'punished' periodically at the ballot box (or not) [7].

Corruption is a reality in Indonesia and has a significant destructive force. Not only does it harm the wealth of the state, but it also takes away the legitimacy of law enforcement by destroying the public's trust in law [8].

Corruption and organized crime are deeply connected phenomena. Even if there does not exist a universally agreed definition of organized crime, social scientists usually insist on the essential role played by corruption and the establishment of deep connections between criminal organizations and the public domain [9].

Since the cross-country literature is unable to provide clear evidence on the consequences of corruption on investment, there is a growing need for studies of corruption within single countries, which benefit from better measures of corruption and stronger homogeneity of political, economic, and social conditions [10].

The criminal act of corruption in the procurement of government goods and/or services is a form of misappropriation of the use of state money or public money that is detrimental to the state's economy [11]. The criminal act of corruption occurring in the Indonesian state prevents the government from prospering its people, because money should be used for the benefit of the people, but used by a handful of people to enrich themselves, their families, and their cronies [12].

Deviation of the use of state finances by exploiting the power possessed by officials has hampered the purpose of the state in the prosperity of its people, thus causing injustice [13]. Whereas the purpose of the Republic of Indonesia in the Constitution of the Republic of Indonesia in 1945, its relation in the effort to prosper the people is the state has the function 
or the task of welfare (welfare function). This task is in the broadest sense, including social service and social welfare, such as natural disaster relief, poverty, unemployment, minimum wage determination, health aid, orphanage, and others. All these activities are intended for the realization of community welfare and social justice for all Indonesian people [14].

Mamesah argues that state finances are rights and obligations that can be assessed with money, as well as everything, either in the form of money or goods that can be used as state property in connection with the exercise of these rights and obligations [15].

Law Number 31 Year 1999 concerning the Eradication of Corruption jo. Law Number 20 Year 2001 concerning Amendment to Law Number 31 Year 1999 concerning the Eradication of Corruption is a law regulating the criminal matter of corruption [16]. Although both laws govern corruption, state finance is also regulated in it, because the criminal act of corruption is categorized as an act that unlawfully can harm the state finance or state economy.

As a result of corruption, public confidence in the government is diminishing. There are almost no government institutions that are free from corruption. Not only in Indonesia, but in other countries of the world corruption is also common. Therefore, the prevention of corruption must be done by countries in the world in cooperation and sustainable. In particular for the Indonesian state efforts should be made not only to prevent corruption but also to eradicate it, since the number of cases, state losses, and modus operandi of corruption continues to increase every year [12].

Combating corruption is a set of measures to prevent and combat corruption (through coordination, monitoring, monitoring, investigation, prosecution and examination in court) with community participation based on applicable laws and regulations [16].

Extraordinary efforts to combat corruption have been rolled out. In the criminal field there has been an upside proof to show that the defendant committed a criminal act of corruption. The sentences given by the judge are also in accordance with the laws and regulations. In addition, the government has worked with other countries to restore the assets of the corrupted country. However, corruption still occurs and even involves many officials [17].

The fact shows that not all policies established by the government to solve problems that occur could be proceeded in accordance with expectations, often the barriers occur in the implementation process so that the purpose of policy issuance achieved. In fact, not a few policies formed by governments that do not work or fail to be implemented.

Based on the facts above, this paper is aimed at investigating strategies of eradicating corruption as an effort to return state asset losses in the procurement of government' goods and/or services.

\section{METHOD}

The type of research is a normative legal research study that is tracked by using conceptual and statute approaches. The data were obtained from literature studies and books of the shrimp that govern corruption. Documentation technique is a technique done to collect data of this research. The data were analyzed by qualitative descriptive method which includes deeply examining the meaning and making inferences to it; then describes the results of the obtained. The legal content was analyzed by hermeneutic technique to understand the definite meaning of each content of the provision made by the government about the act of eradicating corruption and to explain it conceptually by making the sense.

\section{RESUlT AND DISCUSSION}

The definition of procurement of goods and services according to a legal dictionary is to buy a job or to request another party to work or to purchase work in whole or in part according to the type of work or contract made by both parties before the charter work is carried out

Public goods/services are goods that are used in connection with the interests of the public, both in small groups and the general public, whereas private goods/services are goods that are only used individually or in certain groups [18]. Based on this classification, goods or services may be categorized as public goods and may also be categorized as personal items depending on their use.

Procurement of goods and/or services by the government should be carried out to fulfill all procurement of goods and/or services for the public interest, to obtain goods and/or services that are domestic products, and to obtain a cheap price of goods in accordance with market price (standard).

The need for goods/services is inevitable in order to maintain operational fluency and ensure the growth of the public sector, which in its acquisition cannot take place instantly, but it takes time. The time span to get it is from ordering, manufacturing, shipping, and processing goods in the warehouse until ready for use by the buyer.

Corruption in the procurement of government goods and/or services is inseparable from the abuse of power/authority by the leader. Abuses of authority by the leader are very visible, both at the executive and legislative levels, the modes can be oral recommendations from the leader, procurement plan directed, auction without tendering, delegate auction delegation, or foiled procurement plan. It indicates the intervention of the ruler or the leader of the auction is intensely strong. Especially if the leader has dual positions as public officials, as well as concurrently as a certain party leader, so sometimes there appears a tendency of qualifications that lead to certain companies that have cooperated with the party.

The modus operandi of corruption in the procurement of government goods/services, increasingly sophisticated time, which is packed in various terms, among others by using the terms giving, remuneration, reminiscence, eye sign, so as if it is not a criminal act of corruption. Corruption is co-existed side by side with nepotism. Nepotism is usually used as a term to describe actions that provide priority to a relative or family, 
colleagues, relationships, and equitable members of a political party, regardless of the prescribed requirements, so as to be passed on as a partner even if they do not meet the qualifications.

Although the provisions governing the procurement of goods and/or services are regulated in a presidential regulation concerning the Procurement of Goods/Services of the Government, a breach in any stage of procurement of goods and/or government services that may be used by some officer, committee or provider of goods/services to commit crimes through various modes is still continues to be made.

Here are the fifteen stages of procurement of goods/services of the government based on Presidential Regulation no. 4 years 2015 jo; Presidential Regulation Number 70 Year 2012 jo.; Presidential Regulation No. 54 of 2010 jo.; Presidential Regulation Number 80 Year 2003 concerning Procurement of Government Goods/Services along with a number of potential deviations:

A. Procurement planning stage, deviation mode:

- Budget inflate;

- Procurement plan which is directed;

- Packaging engineering for corruption, collusion and nepotism.

B. The stages of forming the auction committee;

- The committee is not transparent;

- The integrity of the auction committee is weak;

- The auction committee who took sides;

- The auction committee is not independent.

C. Prequalification stage of the company;

- Administrative documents which are ineligible;

- The administrative document "original but fake";

- Legalization of documents is not done;

- Evaluation does not match criteria.

D. The stages of preparation of tender documents;

- Specifications are directed;

- Engineering evaluation criteria;

- Non-standard auction documents;

- Incomplete auction document.

E. Stages of auction announcement;

- Fake or fictitious auction announcements;

- The auction announcement is incomplete;

- The announcement period is too short.

\section{F. Stage of auction documents collection;}

- The auction document which is submitted is not the same (inconsistent);

- Document distribution time is limited;

- Document retrieval location is difficult to find.

G. Stage of self-estimate price preparation (HPS);

- Description of self-estimate price covered up;

- Mark up for corruption, collusion and nepotism;

- The basic price it's not standard (in corruption, collusion and nepotism);

- The determination of price estimation is not according to the rules.

H. Stages of explanation/aanwijzing;

- Pre-bid meeting which is limited;

- Information and description are limited;

- Controversial explanation.

I. Stage of submission and opening of the offer;

- Relocate places submission of bid documents;

- Acceptance of bid documents which are late;

- Submission of fictitious documents.

J. Stage of bid evaluation;

- Faulty evaluation criteria;

- Replacement of the bid document;

- The evaluation is closed and hidden;

- Bidders are patterned in order to collude.

K. Stages of announcement of potential winners;

- Limited announcements;

- The announcement date is delayed;

- An announcement that is not in accordance with the rules of the announcement.

L. Stage of disclaimer;

- Not all complaints are responded;

- The substance of the rebuttal is not addressed;

- Proforma rebuttal to avoid bidding allegations has been arranged.

M. Stages of appointing the winner of the auction;

- Letter of appointment which is incomplete;

- Letter of appointment which deliberately postponed its expenses; 
- Letter of appointment issued in haste;

- Unauthorized appointment letter.

\section{N. Stages of signing the contract;}

- The signing of the contract is delayed;

- The contract signing is closed;

- Signing of contract is not valid.

\section{O. Stages of delivery of goods/services.}

- Unequal volume;

- Quality of work is lower than the requirements in the technical specifications;

- The quality of work is not the same as the technical specification;

- Contract change order.

From the bureaucratic stage of procurement of government's goods/services, it is known there are potential irregularities that can lead to abuse of authority and corruption. Potential deviation from the bureaucratic stage of procurement of government goods/services is a form of juridical issues in the presidential regulation that the effect is sustainable in the form of structural problems to the existence of institutions/agencies as a means of procurement activities of goods and services and cultural issues related to quality and competence of resources human in implementing procurement of goods/services.

Crime of corruption on the procurement of government goods/services, potential done by partners or managers of goods/service's procurement (PA/KPA, PPK, ULP, and Committee of Beneficiaries/Services). Usually, the risk of a criminal offense on procurement of government goods/services is conducted jointly or known as "congregational corruption." The consequences of such acts for the perpetrator that is the committee and the associates are damaged reputation. Officials who are proven to be corrupt will certainly not gain the trust of the people, their names will be tarnished, and will be sanctioned both administrative and criminal sanctions. For partners, if proven to corrupt, then the name of the company will also be smeared, will be blacklisted so it cannot follow the tender to be held by the government again, and of course criminal sanctions are also ready to wait. The perpetrator of corruption must also compensate for the consequences of his actions.

Some of the perpetrators did not realize that the risk of criminal offenses was severe. Costs or losses incurred due to criminal acts on procurement of goods/services are unequal compared to expected profits (more losses than profit earned).

To improve the effectiveness and efficiency of the state's financial use and to prevent any state financial leakage indicating corruption in the procurement of government goods/services, it is necessary to improve the quality of public services by the government bureaucracy through good and clean governance by implementing the principles of good governance and clean government supported by effective, efficient, transparent and accountable financial management. In addition, the Indonesian state that has ratified UNCAC 2003 as stipulated in Law No. 7 of 2006 on Ratification of UNCAC 2003, in order to prevent and eradicate corruption, Indonesia cooperates with the international world, especially in terms of returning the results of criminal acts of corruption. The main content of UNCAC 2003 is corruption prevention and government procurement policy, which is one of the strategies to prevent and eradicate corruption, including corruption in procurement of government goods and/or services.

Strategy or efforts to overcome the problem of corruption can be viewed from the structure or social system, in terms of juridical, as well as terms of ethics or morals of man. One thing that is clear is that corruption is an official behavior that deviates from the norms already accepted by society, and that is used to achieve personal goals. Meanwhile, corruption also becomes an inevitable phenomenon in every system of government. There is not a truly sterile social system from corruption because there will always be individuals who like to choose shortcuts for self-interest even though they know with full awareness that their actions are morally unjustifiable. Therefore, thing required is a constant awareness of the dangers of corruption and uncompromising attitudes toward the seeds of corruption.

In order to prevent and eradicate corruption in the procurement of government's goods and/or services and to restore state loss's assets due to corruption, the authors propose several strategies, namely:

1) Mental and spiritual coaching of state organizers: This strategy is primarily for the procurement of government goods and/ or services, so it is expected to increase the spiritual quality of the state organizers and awaken the responsibility of the state organizers to carry out the mandate of the people. For this strategy, it can be done in an effort to better understand and deepen the teachings of religion, which can be done by the government or each government institution.

2) Centralize the procurement of government goods and/or services to streamline the function of supervision and to effectively and efficiently stage or bureaucracy the procurement of goods and/or services so as not to be too long and complicated by simplifying the bureaucracy of procurement of government goods and/or services; Implementation of procurement of government goods/services conducted by each government institution, certainly not effective and efficient. In addition, lack of understanding of the procurement of government goods/services guidelines, the organizers who are employees in relevant institution cannot carry out routine tasks well, because it also must participate in the procurement of government goods/services. The supervisory factor is also very important. Lack of supervision in the procurement of government goods/services facilitate unscrupulous organizers perform irregularities. As one of the efforts that can be done is the procurement of government goods/services implemented by a special institution granted authority to organize the procurement of government goods/services. 
The new institution is based in the center, responsible to the president, which will then be established in every province responsible to the governor, as well as in the districts. Thus, this new institution is centralized to facilitate the implementation of procurement of goods/services and supervision.

In the institution also established the supervisory board, and in addition every institution that organizes the procurement of goods/services also acts as a supervisor. If there is any indication of irregularities in the procurement of goods/services carried out by the new institution, the relevant institution may cancel the procurement of goods/services, so as to create checks and balances, and with centralization of government procurement will create public accountability in governance.

The simplification of the stages of procurement government of goods and/or service's activities, which originally there are 15 phases simplified into seven stages, namely the preparation stage, the prequalification stage and the preparation of corporate documents, stage of self-estimate price preparation and aanwijzing, the stages of announcement of the winner of the auction, the stages of signing the contract, implementation of work, as well as stages of job submission.

Indonesia can also imitate the procurement of goods/services in South Korea that have been successful in implementing e-procurement. In South Korea, e-procurement is known as Korea's On-line E-Procurement System (KONEPS). The institution that serves e-procurement service in Korea is Public Procurement Service (PPS). It takes a high commitment to be able to implement e-procurement as KONEPS in South Korea.

In Singapore, public services use a one-stop online system, as well as an online procurement program called GeBIZ (Government Electronic Business). GeBIZ was built since 2000 which is a portal of public e-procurement. Providers of goods and services can conduct e-commerce activities with the Singapore government. All tender offerings up to the announcement of winners are listed in GeBIZ, so providers can search for government tender offerings, download procurement documents, and provide their offer by online.

3) Strengthening preventive action to minimize the potential for corruption in the procurement of government goods and/or services: As a preventive effort, it can be done with the improvement of moral and religious education. The problem of corruption is closely related to the moral and ethical issues in the state's administration. To overcome these problems, namely ethical and moral issues need to have ethical and moral education in addition to religious education that must be instilled since childhood and when already working as a state apparatus. This moral and ethical education can foster a sense of embarrassment if it violates the laws and regulations, so that if the state apparatus implement the procurement of government goods/services while upholding the moral and ethical, certainly there will be no irregularities. Accountability and transparency will be realized if every state apparatus has good ethics and morals. This transparency is also applied in the recruitment of state apparatus. If in the recruitment of employees there has been a deviation, then for the next will also occur irregularities.

The high ethics and morals of the state apparatus will also raise aware-ness for the state apparatus to obey the law. Of course, the regulations should be socialized. Not because they have been deemed to know the rules of the prevailing laws. Ignorance of the prevailing laws and regulations, in the end will lead to incomprehension, and such misunderstandings can lead to many perceptions and irregularities in the implementation of legislation. The fault may not be only in the state apparatus which is required to comply with all regulations, but the number of regulations and constantly changing cannot be consistently carried out by any state organizer.

As stated by Jeremy Pope that strategies to control corruption should therefore focus on the "opportunity and desire" element. Opportunities can be reduced by systematically making changes, while desires can be reduced by reversing "high profit, low risk" tactics into "low profit, high risk", by preventing, enforcing the law, and frightening effectively and enforcing accountability mechanisms. In addition, in order to succeed a strategy must not only focus on enforcing the law and imposing sanctions, but also on prevention efforts and public education.

In addition, it is also necessary to increase understanding on procurement of government goods/services for all procurement officers (head of institution/ agencies, PPK, committee/procurement officer, treasurer, and officials/other related officials), so there is no deviation procedure.

4) The imposition of sanctions or social work penalties for corruptors, namely by employing corruptors in public places during the sentence: Social work penalties can be imposed on a defendant in a corruption case along with imprisonment and a fine. This social work penalty aims to foster a sense of shame for the perpetrators of corruption so that it can cause a deterrent effect.

The strategy proposed by the authors above, is expected to prevent and eradicate corruption in the field of procurement of government goods and/or services and return the state financial losses resulting from the criminal act of corruption.

\section{CONCLUSION}

In order to prevent and eradicate corruption in the procurement of government goods and/or services, and to restore state losses assets due to corruption, several strategies are proposed: (1) mental and spiritual coaching of state officials; (2) centralizing the procurement of government goods and/or services, and simplifying the stage or bureaucracy of procurement of goods and/or services so as not to be too long and convoluted; (3) strengthening preventive action to minimize the potential for corruption in the procurement of government goods and/or services; and (4) imposition of sanctions or social work penalties for corruptors, that is by employing corruptors in public places during the sentence. 


\section{ACKNOWLEDGEMENT}

The author would like to thank all the parties who have helped and contributed in the writing of this article, both those who contribute in the form of funding and critical ideas. Hopefully this paper can be useful theoretically and practically for the addition and development of knowledge, especially in the field of legal science.

\section{REFERENCES}

[1] A. Maheka, Mengenali \& Memberantas Korupsi, Komisi Pemberantasan Korupsi. Jakarta.

[2] I. Nurdjana, Sistem Hukum Pidana dan Bahaya Laten Korupsi "Perspektif Tegaknya Keadilan Melawan Mafia Hukum," First Edit. Yogyakarta: Pustaka Pelajar, 2010.

[3] J. H. Arsyad, Korupsi Dalam Perspektif HAN (Hukum Administrasi Negara), First Edit. Jakarta: Sinar Grafika, 2013.

[4] W. G. Tierney and N. S. Sabharwal, "Academic corruption: Culture and trust in Indian higher education," Int. J. Educ. Dev., vol. 55, no. May 2016, pp. 30-40, 2017.

[5] C. Joseph Joseph, J. Gunawan, Y. Sawani, M. Rahmat, J. Avelind Noyem, and F. Darus, "A comparative study of anti-corruption practice disclosure among Malaysian and Indonesian Corporate Social Responsibility (CSR) best practice companies," J. Clean. Prod., vol. 112, pp. 2896-2906, 2016.

[6] D. Ryvkin and D. Serra, "Corruption and competition among bureaucrats: An experimental study,” J. Econ. Behav. Organ., no. 2018, 2018.

[7] B. G. López-Valcárcel, J. L. Jiménez, and J. Perdiguero, "Danger: Local corruption is contagious!,” J. Policy Model., vol. 39, no. 5, pp. 790-808, 2017.
[8] S. Isra, Yuliandri, F. Amsari, and H. Tegnan, "Obstruction of justice in the effort to eradicate corruption in Indonesia," Int. J. Law, Crime Justice, vol. 51, pp. 72-83, 2017.

[9] A. Gamba, G. Immordino, and S. Piccolo, "Corruption, organized crime and the bright side of subversion of law," J. Public Econ., vol. 159, no. February 2017, pp. 79-88, 2018.

[10] N. Zakharov, "Does Corruption Hinder Investment? Evidence from Russian Regions,” Eur. J. Polit. Econ., no. 33, 2017.

[11] M. Ali, Hukum Pidana Korupsi Di Indonesia, First Edit. Yogyakarta: UII Press, 2011

[12] Rohim, Modus Operandi Tindak Pidana Korupsi. Depok: Pena Multi Media, 2008

[13] J. Pope, Strategi Memberantas Korupsi, Elemen Sistem Integritas Nasional, Buku Panduan Transparency Interbational 2002, First Edit. Jakarta: Yayasan Obor Indonesia, 2003.

[14] J. Hafidz, Strategi Pemberantasan Korupsi Dalam Perspektif Hukum Administrasi Negara. Semarang, 2009.

[15] Muchsan, Sistem Pengawasan Terhadap Perbuatan Aparat Pemerintah Dan Peradilan Tata Usaha Negara Di Indonesia. Yogyakarta: Liberty, 1992.

[16] M. Yahya, Buku Pintar Pengadaan Barang \& Jasa Pemerintah, Sesuai Dengan Perpres. Jakarta: Laskar Aksara, 2012.

[17] "Lembaga Kebijakan Pengadaan Barang/Jasa Pemerintah, Senarai Pengadaan Barang/Jasa Pemerintah, Lembaga Kebijakan Pengadaan Barang/ Jasa Pemerintah (LKPP),”J. Pengadaan, 2011.

[18] D. Munir, Kebijakan \& Manajemen Keuangan Daerah. Yogyakarta: YPAPI, 2004 